\title{
Bí quyết khởi nghiệp từ con số 0
}

\section{MISA Việt Nam}

$$
\text { April 18, } 2013
$$

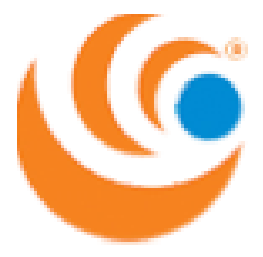

https://www.misa.vn/21284/Bi-quyet-khoi-nghiep-tu-con-so-0/ 


\section{Bí quyết khởi nghiệp từ con số 0}

18 Tháng Tư, 2013

Rất nhiều, rất nhiều người nghĩ rằng khởi nghiệm là rất khó khăn, cần nhiều vốn và kiến thức... hay nhiều điều kiện tiền đề. Nhưng cũng có không it người khởi nghiệm cũng đến rất tình cờ, dễ dàng như là duyên số.

Quả thực khởi nghiệp có khó khăn đến như vậy không, bài viết dưới đây đề cập đến một khái niệm là tiền đề cho việc khởi nghiệp mà bất kỳ ai cũng có thể làm được đó là Thương hiệu cá nhân.

Trong công ty chúng tôi có một khẩu hiệu: Muốn làm được việc lớn, phải làm tốt những việc nhỏ. Và một nguyên tắc nữa là không giao việc lớn khi chưa làm tốt việc nhỏ, không giao tiền lớn khi chưa biết tiêu tiền nhỏ. Làm tốt việc minh đang làm thi tự động tiền bạc nó sẽ đến.

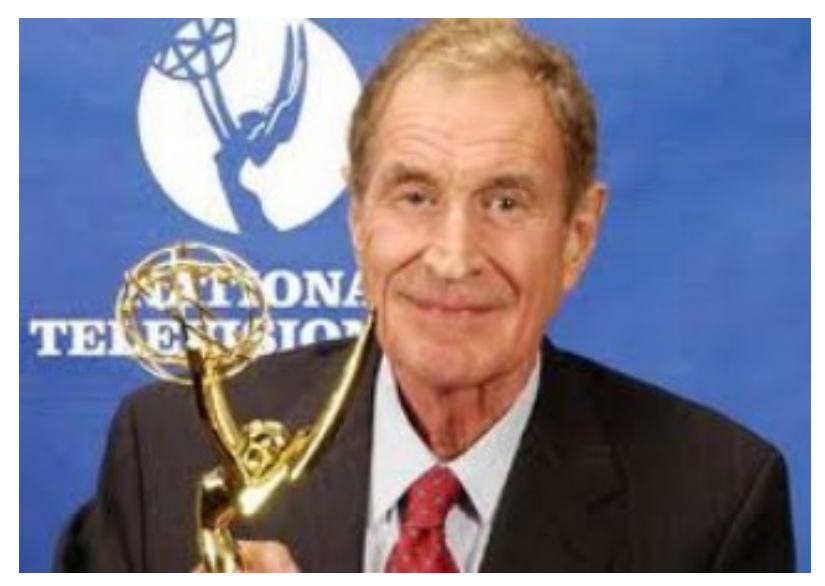

Quả thực theo tôi nghĩ, khởi nghiệp không quá khó khăn như ta tưởng đến thế. Khi tôi làm tốt những khoản đầu tư nhỏ, có những đánh giá tốt, thi công ty giao cho tôi những khoản tiền lớn. Khi tôi chứng minh được khả năng xài tiền lớn thi lại càng nhiều tiền được giao cho tôi. Uy tín và thương hiệu cá nhân có lẽ là cái cơ bản nhất để khởi nghiệp.

Thương hiệu cá nhân được xây dựng từ những hành vi nhỏ nhặt nhất. Nếu không xây dựng được thương hiệu cá nhân thì chắc là khi khởi nghiệp sẽ có rất nhiều "cái lưng" xuất hiện. Tại công ty chúng tôi, vấn đề vốn kinh doanh không phải là vấn đề chính, nếu có ý tưởng tốt, được một người trung thực hiểu biết xây dựng thì chắc chắn không 
có lý do gi mà không được công ty xem xét để tài trợ vốn đầu tư. Có lẽ chính vì lý do đó mà công ty mặc dù không to nhưng có vẻ luôn năng động.

Tôi được tặng một cuốn Văn Minh làm giàu và Nguồn gốc của cải của TS. Vương Quân Hoàng, tiếc rằng trong cuốn sách này không thấy có đề cập đến vấn đề Thương hiệu cá nhân để khởi nghiệp. Mong các bạn suy nghĩ về vấn đề này. Tôi cũng được một anh động viên viết một bài về hoặc một cuốn về Thương hiệu cá nhân. Khái niệm tuy không mới nhưng tôi nghĩ là cái xuất phát của mọi thành công.

\section{MISA}

(/)

CÔNG TY (/CONG-TY) TIN TƯC (/TIN-TUC) TUYỂN DỤNG (HTTP://MISA.JOBDAY.VN) HƠP TÁC (/HOP-TAC) LIÊN HẸ (/LIEN-HE)

Tầng 9, tòa nhà Technosoft, phố Duy Tân, phường Dịch Vọng Hậu, Q. Cầu Giấy, TP. Hà Nội

Giấy CNDKKD: 0101243150 - Ngày cấp: 22/04/2002, được sửa đổi lần thứ 14 ngày 23/07/2018

Cơ quan cấp: Phòng Đăng ký kinh doanh - Sở Kế hoạch và Đầu tư TP. Hà Nội

(https://www.dmca.com/Protection
/Status.aspx?ID=806ea618-1dc3-47d3-9a25-
d282d6d34cea\&refurl=https://www.misa.vn/21284/Bi-
quyet-khoi-nghiep-tu-con-so-0/)

Copyright ${ }^{\oplus} 1994-2021$ MISA JSC

sách bảo mật //www.misa.vn :y/) | Thông nh toán //www.misa.vn s/quy-dinh$\begin{array}{ll}\text { (https://www.youtube.com } & \text { (https://www } \\ \text { /user/MISAJSCchannel) } & \text { /MISAJSC) }\end{array}$

\section{f} h-thuc-

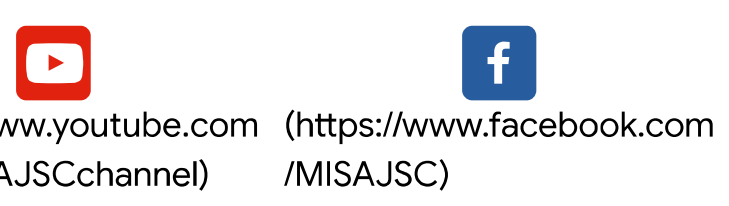

(http://online. /Home/Web[ 165890)

toan/) 
Tài liệu tham khảo:

[1] Đào Duy Anh. (1938). Việt Nam văn hóa sử cương. Quan Hải Tùng Thư, Huế (Imprimerie du Mirador).

[2] Vương Quân Hoàng. (2007). Văn minh làm giàu \& Nguồn gốc của cải. Nxb Chính trị Quốc gia, Hà Nội. 